Témoigner Témoigner. Entre histoire et mémoire

Getuigen Revue pluridisciplinaire de la Fondation Auschwitz

$125 \mid 2017$

Histoire et mémoire de la persécution des

homosexuel·le's par les nazis

\title{
Dunkirk: Het mirakel van een evacuatie (Christopher Nolan)
}

\section{Brecht Capiau}

\section{(2) OpenEdition}

Journals

Édition électronique

URL : https://journals.openedition.org/temoigner/6234

DOI : $10.4000 /$ temoigner.6234

ISSN : 2506-6390

Éditeur :

Éditions du Centre d'études et de documentation Mémoire d'Auschwitz, Éditions Kimé

Édition imprimée

Date de publication : 1 octobre 2017

Pagination : 20-22

ISBN : 978-2-930953-01-4

ISSN : 2031-4183

Référence électronique

Brecht Capiau, «Dunkirk: Het mirakel van een evacuatie (Christopher Nolan)», Témoigner. Entre histoire et mémoire [Online], 125 | 2017, Online op 21 décembre 2021, geraadpleegd op 03 février 2022. URL: http://journals.openedition.org/temoigner/6234 ; DOI: https://doi.org/10.4000/temoigner.6234 


\section{DUNKIRK: HET MIRAKEL VAN EEN EVACUATIE (CHRISTOPHER NOLAN)}

FILM Eind mei 1940. De Slag om Frankrijk loopt op zijn einde. De Britse, Franse en Belgische troepen worden overal in het defensief gedrongen en in de richting van de zee gedreven. The British Expeditionary Force (BEF) en een restant van het Franse leger verzamelen in Duinkerke voor evacuatie, op de hielen gezeten door de Duitse troepen. Plots gebeurt het

ondenker. 24 meibereelt Adolf Hitter go antraden von Rundstedt en Günther von Kluge het Duitse leger om hun opmars te stoppen. Het historisch beruchte 'Halt Order' zorgt er echter voor dat de Geallieerden voldoende tijd krijgen om een verdedigingslinie rond Duinkerke op te trekken én Operatie Dynamo, de evacuatie van de Geallieerden naar Engeland, te organiseren. Meer dan 330000 van een geschatte 400000 soldaten worden tussen 26 mei en 4 juni gered van wat mogelijks de grootste militaire catastrofe uit de wereldgeschiedenis had kunnen zijn.

"Wars are not won by evacuations"

De Britse premier Winston Churchill in een speech voor The House of Commons over de evacuatie bij Duinkerke in mei 1940.

DE OORLOGSFILM REVISITED

Devacuatie in Duinkerke in de begindagen van de Tweede Wereldoorlog is het onderwerp van Dunkirk de nieuwe film van de Brits- Amerikaanse regisseu christophid Nolan. De kiem van de rolprent werd cezaaid tijdens een overstoek van het Bitse kanal jong volde en in nog geen enkele arvarich toen te on

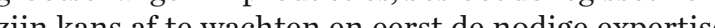
op te doen. Het eit op te doen. Het entoris op vele vlakken en toont een regisseur op het toppunt van zijn creatieve krachten. On te beginnen gebruik. volan drie verschillies tijdens drie verschillen op drie fases. In ases. In het eerste kwartier van de film worden ze kort voor ons geschetst.

Hetite 'The Mole' van Tommy, een jonge Britse soldaat die wacht op zijn evacuatie bij een van de pieren die Duinkerke rijk is. Dit luik van de film beslaat een week. Het tweede vertelperspectief heet 'The Air' en volgt Farrier en Collins, twee RAF-piloten die gedu-

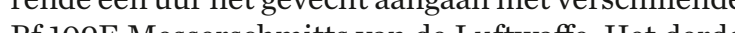
Bf vijds hetvert zich het verhal Man de civie bo bije de civiele boten die The Royal Navy oproept om te komen helpen. Anderzijds zien we ook wat er gebeur met de reeds ingescheepte soldaten die op wegzijn naar Engeland. De filn wornt dus als het ware een triptiek waarbij je te land, ter zee en in de lucht een overzich de Geallieerden mee te kapen kregen. Boveerden mee te kampen kregen.

Bovendien wordt dit geheel op een non-lineaire manier gepresenteerd waardoor je je op het ene

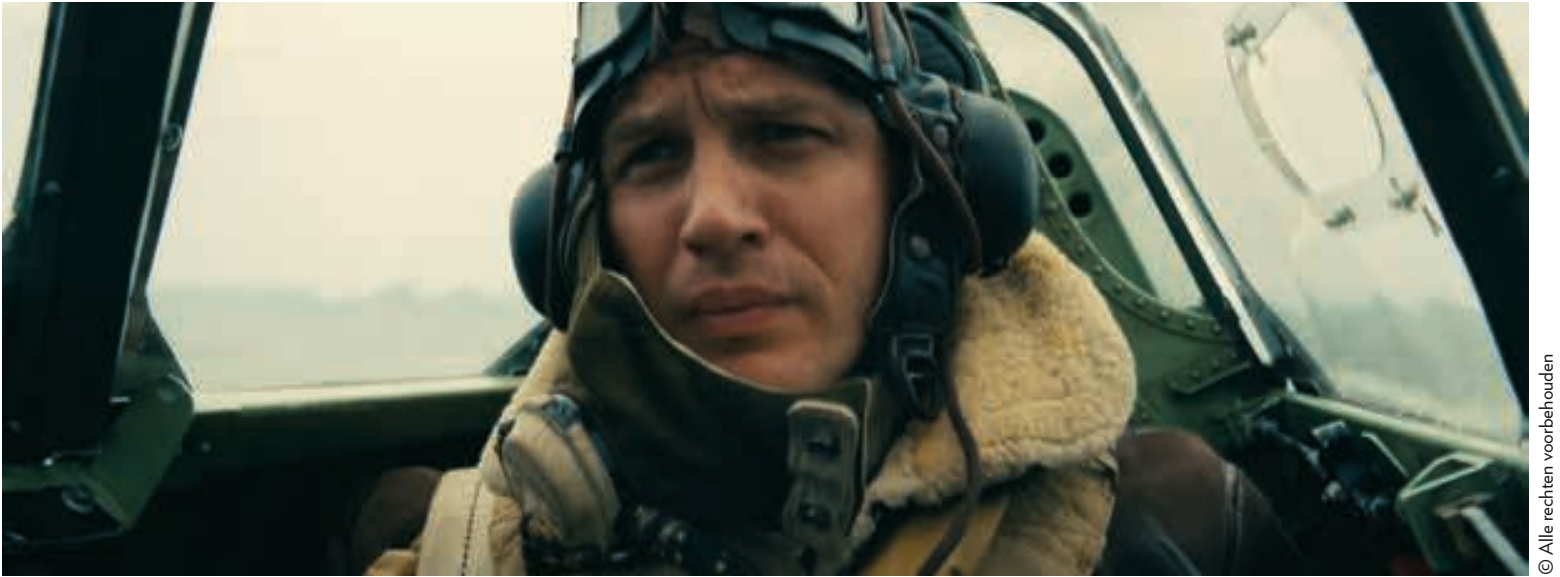

torpedobootjager bevindt en op het andere moment een luchtgevecht ziet tussen Britse Spitfires en Duitse Messerschmitts.

Wat Dunkirk onderscheidt van andere blockbusters is het gebrek aan dialoog en een absoluut vertrouwen om hetve tellen. We kennen de namen van de personages, mar

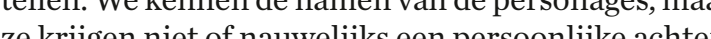
ze krijgen niet of nuwerijks een persoonlijke achtergrond warije kijken zichelf zichzelf or ander te verklaren. Een gemiddelde film de kijker dzakelijk op de enotionele identificatie van dekijker van onze zin of weerzin on mee te gaan in hun perniet Slechts weinig regisseurs zijn in stat om ict. Slo het publiek wel the the ame, vertolkt door Clint Eastwood, in de Dollars triDunkirk ceen het lot van zijn vele piepionge karakts. De het lot van zijn vele piepjonge karakters. De manier waarop Mr. Dawson ongaat meteen personage dat lijd a dat vlak boekdaten Wann Disor de (PTSD) spreekt op dat vlak boekdelen. Wanneer de schipper met zijn boot onderweg is naar de stranden door Cillian Murphy, die vor zich uit door Cillian Murphy, die voor zich uit zit te staren op de boeg van een zinkend schip. Het is snel duidelijk dat de man een zware traumatische ervaring achter 'slagveld' De serenten beding terug wil nat anpakt getuigt van een sterk inzicht in de menselijke psyche en een empathie voor kwetsbare personen die we vandaag te weinig zien in speelfilms van die omvan. Wat de cinematografie betreft, valt vooral het IMAX 70 $\mathrm{mm}$ formaat op. Visueel onderstreept dit niet alleen de rootschaligheid van de evacuatie, maar helpt het oo in de kijker volledig onder te dompelen in het gebeuAls oorlog film tapt Durkirk ook uit een an

Als oorlogsfilm tapt Dunkirk ook uit een ander derits (1953) en The DrBusters (1955) blonken net als Durirk uit in warBusters (1955) blonken net als Dunkirk uit in waartienja rna de Wereldoorlogwas datooknodig ch jat de dan on de ooth zer bevedigend dat Nolan teruggijpt naar lescric besser gevaar en te gekleure, eer pathetische bril toen bekijken. Een ander opvalijende ken. Een andere opvallende gelijkenis met de hogergen zien die an flarden zijn gereten door bommen of andere, uit dat de constante psychologische stress die uit dat de constante psychologische stress die een oorlog met zich meebrengt minstens even levensbeDunkirk is a Dunkirk is ook geen verhaal van politici, maar van de de re die aan farden zijn gereten door bonnen of andere, 
-.. De beroemde 'We Shall Fight on The Beaches'speech op het einde van de film wordt niet uitgesproken door de auteur zelf, Winston Churchill, maar door Tommy, een geëvacueerde soldaat, die de tekst voorleest uit de krant. Het is niet moeilijk om deze scène als een soort ironisch commentaar van de regisseur zelf te zien. Uiteindelijk zullen het niet de politici zijn die zullen vechten op de stranden, maar wellicht de mannen die de woorden lezen in de pers. Tenslotte speelt Nolan in deze scène ook een semantisch spelletje met het woord 'Tommy': niet toevallig is het naast een persoonsnaam ook de bijnaam voor alle Britse soldaten tijdens de Tweede Wereldoorlog.

\section{DE PLAATS VAN DUNKIRK}

\section{IN HET OEUVRE VAN NOLAN}

'Show them what they have, and then you takeitaway', zegt inbreker Cobb tegen zijn leerling Bill in Following (1998), het debuut van Christopher Nolan. Al van bij het begin van zijn carrière is Nolan geïntrigeerd door wat in het Engels 'con artists' wordt genoemd: mannen die erin slagen om op een verbluffende manier hun medemens te bedriegen en daarna te ontsnappen aan de gevolgen van hun daden. Bijna alle films van Nolan spelen in meerdere of mindere mate met dit gegeven. Soms letterlijk zoals in The Prestige (2006) waarin twee rivaliserende goochelaars elkaar de loef willen afsteken met de truc 'The Real Transported Man', maar het kan evengoed figuurlijk en symbolisch zoals in Inception (2010). In die film doet Dom Cobb aan bedrijfsspionage door ideeën uit het onderbewuste van zijn 'klanten' te stelen. Dunkirk past wonderwel in dit rijtje. Voor Nolan is dit immers een waargebeurde 'ontsnappingstruc'. In het begin van de film toont de regisseur wat de Duitsers virtueel in handen hebben: 400000 vermoeide, hongerige soldaten die opeengepakt zitten op een strand.
Op het einde blijven er slechts enkele tientallen van de typisch Britse soepbordhelmen over op een compleet verlaten strand. De geallieerden 'toveren' als het ware de overgebleven soldaten weg waardoor de Duitsers met lege handen achterblijven.

Niettemin kunnen we eerder spreken van een variatie op het thema. Om te beginnen is dit zowat de kortste film sinds het begin van de carrière van Christopher Nolan. Het originele scenario telde slechts 76 pagina's, de helft van een gemiddeld scenario. Bovendien verlaat Nolan de bombast van zijn vorige films en kiest hij voor een uitgepuurde vorm van filmmaken om een verhaal te vertellen dat gebaseerd is op waargebeurde feiten. Een verhaal dat nooit uitleggerig wordt en door zijn summiere historische duiding het publiek de ruimte geeft om zelf op onderzoek te gaan. Een verhaal dat, ondanks de beperkte uitwerking van zijn personages, vol emotie zit door de bijzondere situatie die wordt geschetst. Extra info of dialoog zou het geheel snel pathetisch of sentimenteel maken. Tot slot is Dunkirk een film die niet gemaakt is naar aanleiding van de zoveelste verjaardag van de evacuatie van Duinkerke. Op die manier raakte het project niet al te zeer besmet door politieke ingevingen of patriottische gevoelens. Ja, meneer Churchill, met evacuaties kan je wel degelijk oorlogen winnen. De toekomst werd er immers door veilig gesteld.

Brecht Capiau

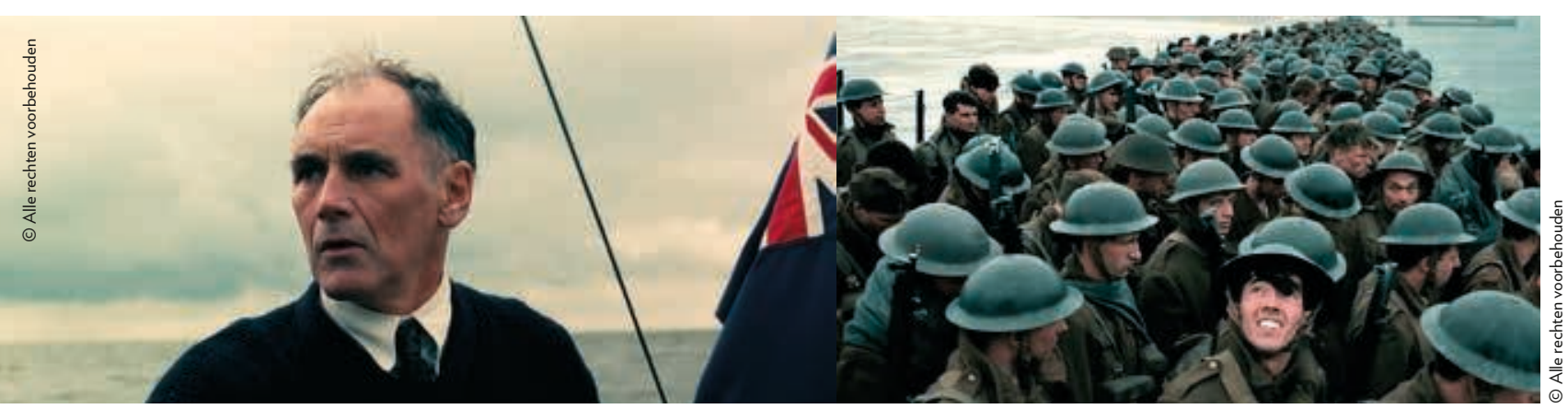

